Meta

Journal des traducteurs

Translators' Journal

\title{
Experimental Studies on Memory in Conference Interpretation
}

\section{Valeria Daró}

Volume 42, numéro 4, décembre 1997

URI : https://id.erudit.org/iderudit/002484ar

DOI : https://doi.org/10.7202/002484ar

Aller au sommaire du numéro

Éditeur(s)

Les Presses de l'Université de Montréal

ISSN

0026-0452 (imprimé)

1492-1421 (numérique)

Découvrir la revue

Citer cet article

Daró, V. (1997). Experimental Studies on Memory in Conference Interpretation. Meta, 42(4), 622-628. https://doi.org/10.7202/002484ar

\section{Résumé de l'article}

Diverses recherches en psychologie cognitive et en neuropsychologie ont démontré que la mémoire n'est pas une fonction unitaire de la connaissance humaine puisqu'elle comprend plusieurs systèmes multi-modaux qui peuvent être mutuellement indépendants. Cet article décrit : a) l'état actuel de la recherche sur $\mathrm{V}$ organisation fonctionnelle des principaux systèmes mémoriels ; et b) le rôle des systèmes mémoriels pendant le processus d'interprétation (tant simultanée que consécutive). La mémoire comprenant de nombreux aspects, selon ces études, il ne peut y avoir une seule et unique façon d'enseigner (et d'apprendre) les techniques et stratégies de la pratique de l'interprétation de conférence qui sont parfois considérées, à ton, comme complémentaires.
Ce document est protégé par la loi sur le droit d'auteur. L'utilisation des services d'Érudit (y compris la reproduction) est assujettie à sa politique d'utilisation que vous pouvez consulter en ligne.

https://apropos.erudit.org/fr/usagers/politique-dutilisation/ 


\title{
EXPERIMENTAL STUDIES ON MEMORY IN CONFERENCE INTERPRETATION
}

\author{
VALERIA DARÒ \\ Scuola Superiore di Lingue Moderne per Interpreti e Traduttori, \\ Università di Trieste, Trieste, Italy
}

\begin{abstract}
Résumé
Diverses recherches en psychologie cognitive et en neuropsychologie ont démontré que la mémoire n' est pas une fonction unitaire de la connaissance humaine puisqu' elle comprend plusieurs systèmes multi-modaux qui peuvent être mutuellement indépendants. Cet article décrit : a) l'état actuel de la recherche sur l'organisation fonctionnelle des principaux systèmes mémoriels ; et b) le rôle des systèmes mémoriels pendant le processus d'interprétation (tant simultanée que consécutive). La mémoire comprenant de nombreux aspects, selon ces études, il ne peut y avoir une seule et unique façon d'enseigner (et d'apprendre) les techniques et stratégies de la pratique de l'interprétation de conférence qui sont parfois considérées, à tort, comme complémentaires.
\end{abstract}

\begin{abstract}
Several studies in cognitive psychology and neuropsychology have shown that memory is not a unitary function of human cognition, since it comprises several multi-modal systems, which can be mutually independent. This article describes: a) the present state of the art on the functional organization of the most relevant memory systems (working memory and explicit vs. implicit memory systems), and b) what experimental studies have so far revealed about the role of mnestic systems during the process of simultaneous and consecutive interpretation. Since these studies suggest that memory is multifaceted, there cannot and should not be a single, unique way to teach and acquire the techniques and strategies of these two types of conference interpretation, which sometimes are erroneously considered reciprocally complementary.
\end{abstract}

The ability to acquire and to retrieve stored information from memory in order to solve different kinds of problems arising in a complex environment is one evolutionary strategy allowing living organisms to better adapt to the surrounding world and, ultimately, to be able to survive (Thompson 1986; Sherry and Schacter 1987). Learning and retrieving acquired information implies the cognitive abilities to perceive and recognize new and past experiences and reorganize them in order to react accordingly to the stimuli.

It should be pointed out from the start that memory is not a unitary function, but rather a range of multi-modal, interrelated systems which can be functionally independent from each other, as clearly seen in pathological instances and neuropsychological research. For the same token, when dealing with memory within the domain of interpretation, one should try to make a clear distinction between all the different types of memory involved in interpreting. In the present article, therefore, I set out to describe the development of the concept of memory in cognitive psychology from the first psychological studies to the most recent theories. Then I will provide a review of the most relevant experimental studies on memory in simultaneous and consecutive interpretation (SI and CI, respectively) in the hope of steering the attention of both practicioners and trainers of interpretation towards this fascinating aspect of knowledge. 


\section{MEMORY MODELS}

About 100 years ago William James (1890) was the first to theorize the distinction between primary and secondary memory, suggesting that there were two related forms of memory storage: one for the information forming the focus of current attention and occupying the stream of thought, and the other for the knowledge of events or facts belonging to former states of mind. The same dualistic approach forms the basis of the modal model by Atkinson and Shiffrin (1968), according to which short term memory (STM) retains information only temporarily so as to allow it to be transferred from here into a more stable, potentially permanent long term memory (LTM) store. Indeed, clinical data showing "double dissociations" between STM and LTM in amnesic patients with brain lesions corroborate the hypothesis of a dual memory system. The case of H.M. who lost the capacity to store new information in LTM with intact STM storage is an example of a dissociation between the two main memory systems, thus showing that one may function independently from the other (Scoville and Milner 1957). Another example of dissociation between LTM and STM, this time with the opposite clinical picture, has been observed in the patient K.F. described by Warrington and Shallice (1969; Shallice and Warrington 1970). After a left-hemisphere lesion, K.F. presented a severe impairment of STM (digit span $=2$, when normal digit span equals $7+(-2)$ with normal LTM. These two opposite memory syndromes represent a clear example of "double dissociation", which corroborates the hypothesis of the existence of two main memory systems. However, patients with deficits in STM, like K.F. for instance, suggested that Atkinson and Shiffrin's (1968) model had to be revisited, since it appeared that integrity of STM was not absolutely necessary in order to store information into LTM.

In addition to this, the question of limited STM capacity which had been observed during neuropsychological experiments (e.g. Miller 1956) led to the development of the concept of working memory, which is supposed to be a memory "buffer" in which information is maintained while it is being processed (Baddeley and Hitch 1974). In particular, Baddeley $(1990 ; 1991 ; 1994)$ suggested a model based on working memory systems, which presupposes the existence of a central executive system controlling the attentional systems connected to a number of slave systems, each one processing information according to its own specific modality. One of these systems is the visuospatial sketch pad, which processes visual images, another is the phonological loop, which accounts for speechbased information. Memory traces of acoustically perceived verbal material that are temporarily processed within the phonological store generally decay and thus become unretrievable after about 1.5 to 2 seconds, unless they are "refreshed" by the process of subvocal rehearsal. By this process the traces are fed back into the articulatory control processes, thus prolonging their presence within the working memory. Similarly, visuospatial images are temporarily set up and maintained on a sort of "scratch pad" to enhance their presence in the working memory accounting for the processing of visual stimuli.

As to LTM, it too should not be viewed as a unitary function, but rather as a multifaceted system with several components (or subsystems), each one representing one modality of information storage that can be functionally independent from the others. Thus, according to Cohen and Squire (1980) a first distinction between declarative and procedural (non-declarative) memory should be made: the former referring to events and facts that are directly accessible to conscious recollection (knowing that), the latter being intrinsecally contained within learned skills or cognitive operations (knowing how). Schacter (1987) rightly points out that declarative memory should be better defined as explicit memory, because it implies conscious awareness and because its contents can be represented or verbalized on demand, whereas procedural memory is a form of implicit memory in that it lacks this kind of awareness and is not overt and susceptible to conscious 
recollection. Explicit (declarative) memory comprises two further subsystems: semantic memory, through which individuals store their encyclopaedic knowledge about the world, and episodic memory which refers to autobiographical recall of one's own experiences. On the other hand, implicit (non-declarative) memory includes motor, cognitive and perceptual skills and habits, priming, simple classical conditioning and nonassociative learning (Kinsbourne 1987; Weiskrantz 1987; Tulving 1987; Squire and Zola-Morgan 1991; see Figure 1).

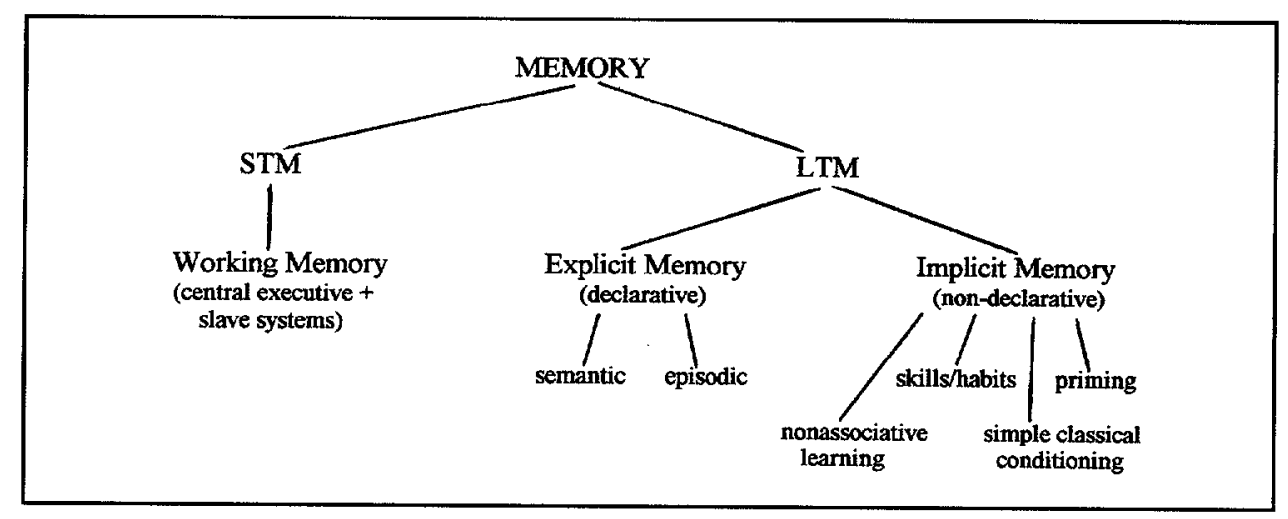

Figure 1:

Different types of memory in a schematic representation.

(Adapted from: Squire and Zola-Morgan 1991)

Paradis (1995) underlines how this kind of memory classification can be applied to language acquisition, learning and use. When acquiring a language, a child unconsciously and automatically applies rules which have been stored in his implicit memory, and the same happens when an adult acquires a second language by repeated and prolonged exposure in an informal setting, thus acquiring communicative competence. On the other hand, if a language is learned within a formal context (e.g. in class) through the conscious interiorization and application of grammatical rules, this is thought to require the activation of explicit memory strategies.

\section{MEMORY AND CONFERENCE INTERPRETATION}

\section{Working memory}

In the mid seventies Gerver (1974) had already observed reduced recall abilities among interpreters after SI as opposed to listening and shadowing. Further research by Lambert (1989) has shown that free recall of verbal material was significantly better after consecutive interpretation as opposed to simultaneous interpretation. The author had suggested that during SI the verbal material was not processed as deeply as in CI and that a less deep processing reduced LTM storage, as theorized by Craik and Lockhart (1972). However, another possible complementary explanation may be suggested: During consecutive interpretation the phonological loop of working memory may be far less interfered than during SI, since in CI articulatory suppression may not be present to the same extent as in SI.

In a recent experimental study Darò and Fabbro (1994) pointed out that reduced recall after SI as opposed to mere listening and shadowing is most probably due to an 
effect of articulatory suppression which hinders the normal functioning of the subvocal rehearsal mechanisms within the phonological loop of working memory. In their experiment, a group of advanced student interpreters showed significantly better recall of short stories after mere listening than after simultaneous interpretation. In addition, memory span for digits was tested in four different conditions: after listening, after shadowing, after articulatory suppression and after simultaneous interpretation. In the condition with articulatory suppression, where the subjects had to pronounce out loud irrelevant syllables while they were listening to the digits, memory span was significantly poorer than after mere listening or shadowing. The lowest span, however, was registered when the digits where simultaneously translated while being presented. As already observed by Baddeley (1990), the operation of the phonological loop is disturbed if overt or covert articulation of an irrelevant item is required during the acoustic or written exposure of the material to be attended to and memorized. If, for example, during a digit span task, subjects are required to utter a stream of irrelevant sound, such as the syllables "bla, bla, bla", span is generally significantly lower. It is assumed, that in this case the articulation of irrelevant syllables dominates the articulatory control process, thus preventing it from being used to maintain material in the phonological store of the working memory. Indeed, the results of Darò and Fabbro (1994) clearly indicate that this kind of articulatory suppression is practically always present during SI, an unusual condition where listening to a message in the source language is concurrent to the production of the same message with a different articulation pattern (target language) and where, apparently, the phonological loop is prevented from working properly. This, in turn, disrupts the normal functioning of working memory, which is thought to be a necessary step for consolidation in LTM. SI represents an extreme paradigm of articulatory suppression, where also attention and translation processes are involved: this would explain why during the above-mentioned experiment the lowest digit span was actually registered in the SI condition (see Fig. 2).

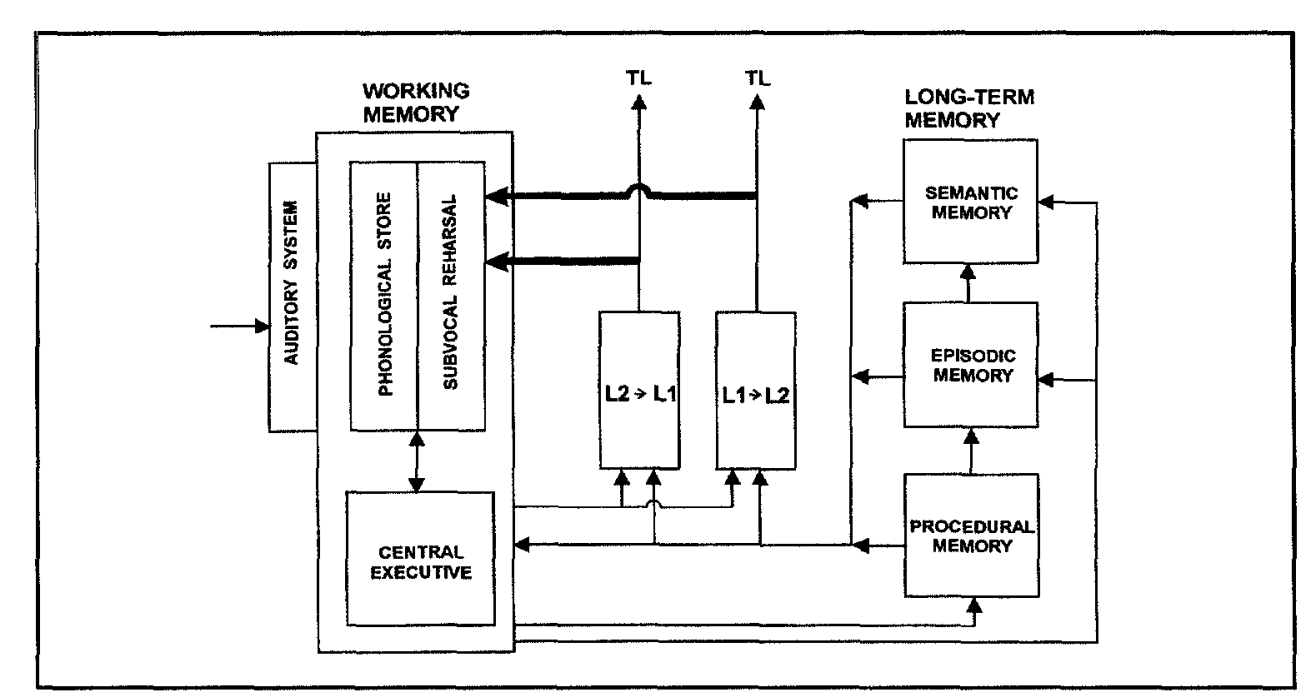

Figure 2:

Memory systems involved in simultaneous interpretation.

The two thick arrows represent the phonological interference exerted on working memory by the oral output in the target language (TL). (Adapted from: Darò and Fabbro 1994). 
In another research study Padilla, Bajo, Cañas and Padilla (1994), found that, in a condition with articulatory suppression, professional interpreters showed significantly better recall of words and digits than non-interpreters. These results confirm once again that during SI there is a mechanism of articulatory suppression. In fact, the superiority of interpreters as opposed to non-interpreters may only be explained by the fact that, through continuous exposure to concurrent listening and speaking, interpreters acquire some strategies to be able to memorize notwithstanding the disruptive effects of articulatory suppression.

Finally, another research study has shown that after SI the ability to recall what is being heard is severely impaired. In his serial study Isham (1994) noticed that verbatim recall of the final clause of a given passage was worse in SI from French into English as opposed to SI from English into ASL, the American Sign Language for the deaf. The main difference between these two performances being the fact that ASL interpreters were dealing with only one spoken language at a time, Isham suggested that there might have been a "phonological interference" caused by the two concurrent speech streams in spoken interpretation.

\section{Long-term memory}

Simultaneous interpreters have thus been found to perform poorly in memory tasks concerning material that they have just translated. Apart from the idea of an impingement on working memory, two other hypotheses can be formulated to account for reduced LTM abilities:

a) The need to divide one's attention between many different concurrent tasks may interfere with the normal activity of the central executive system of the working memory, in a way that it is somehow "overwhelmed" by the accomplishment of all these tasks (Darò 1989; Lambert 1989).

b) Since professional interpreters are daily exposed to a huge amount of (new) information, the majority of which is irrelevant for their personal life and in most cases uninteresting, they might have unconsciously developed a strategy which allows them to "censor" all this redundant material. Both hypotheses would account for simultaneous and consecutive interpretation in a similar way, but probably to a different extent.

Several works of experimental psychology, however, have shown that complex cognitive tasks requiring divided attention do improve with training and task-specific practice (Spelke, Hirst and Neisser 1976; Hirst, Spelke, Reaves, Caharack and Neisser 1980). This is a typical example of acquisition behaviour implying strategies of implicit memory (Graf and Masson 1993). For the same token, some skill components of the process of interpretation (e.g. concurrent listening and speaking as in SI, concurrent listening and taking notes as in CI, divided attention, speaking speed, etc.) may also be improved by means of specific, repeated exercises. It should be noted, however, that the majority of the components of the interpretation process are related to implicit, highly automatized strategies, which, as underlined by Paradis (1995), cannot be enhanced through explicit strategies. In order to acquire interpreting skills, therefore, explicit (theoretical) knowledge on the processes of interpretation is not as relevant as the implicit exercising of the different subcomponents of the whole process.

Although no specific studies have been carried out yet, it is reasonable to believe that semantic memory in interpreters may constantly increase, as in most other professionals who acquire new knowledge through exposure and practice. On the other hand, some aspects of implicit strategies of procedural memory, which are highly relevant in order to be able to carry out interpretation tasks, are subjected to a slow decay due to aging, 
and this may become far more detrimental for an interpeter than for other professionals. For example, a philosopher suffering from Parkinson's disease (a degenerative neurological disease that destroys subcortical structures subserving implicit memory) may still continue his professional activity, even if slowed down, whereas this kind of pathology in an interpreter would cause the loss of his / her most precious abilities related to automatized procedural skills (see Aglioti and Fabbro 1993; Fabbro 1995).

\section{Consecutive interpretation and memory}

A general obvious statement about $\mathrm{CI}$ is that it requires a "sound memory" to be accomplished (e.g. Weber 1984; Seleskovitch and Lederer 1989), but paradoxically memory as a skill component of CI has been empirically less studied than in SI.

Even though in CI there might not be any direct phonological overlapping between two different linguistic codes, it is reasonable to suggest that concurrent listening and writing of notes might well interfere. In addition, some kind of phonological interference can be presupposed also when writing under dictation, since there must be an inner phonological representation of the sounds heard, before they are transcoded into script. In particular, by following Baddeley's model of working memory, this could also impinge on the process of transformation of orally presented phonological material into written material. Baddeley (1990) found a significant reduction in recall ability in subjects who were asked to read and memorize English words during articulatory suppression (i.e. concurrent overt production of irrelevant syllables, like "the, the, the"). One may suggest that if words or syntagmatic units are noted in CI as "symbols" and not in letters, the phonological interference between oral and written material should be reduced, because symbolic representations of verbal utterances may not require an "inner articulation" of their phonological form while they are being noted. By reducing phonological interference, the mechanisms of working memory may function with less constraints, thus facilitating LTM storage of the acoustically perceived verbal material (Darò 1995).

Moreover, I tentatively suggest that during CI episodic memory may be particularly involved, since during the reconstruction phase of the message in the target language, interpreters may possibly try to support their memory for contents by recalling and going over again the episode which marked the presentation of that particular piece of information.

\section{CONCLUSIONS}

Further research still has to be accomplished in oder to better understand how exactly memory is involved in the process of interpretation, and in particular what types of memory are activated in the different interpretation modalities (SI, CI, escort interpreting, etc.). What has been presented here is an attempt to make interpreters, student-interpreters and, possibly, also their trainers realize that memory is multifaceted and that it is not enough to simply state that "interpreters have to improve their memory skills" or that one of the prerequisites of a good interpreter is a sound memory. There is no such a thing like "a" memory. This is again another evidence for the fact that there cannot be a single, unique way to teach and to acquire the techniques and the strategies of simultaneous and consecutive interpretation.

\section{REFERENCES}

AGLIOTI, S. and F. FABBRO (1993): "Paradoxical Selective Recovery in a Bilingual Aphasic Following Subcortical Lesions", NeuroReport, 4, pp. 1359-1362.

ATKINSON, R. C. and R. M. SHIFFRIN (1968): "Human Memory: A Proposed System and its Control Processes", K.W. Spence and J.T. Spence (Eds.), The Psychology of Learning and Motivation: Advances in Research and Theory, vol. 2, New York, Academic Press, pp. 89-195. 
BADDELEY, A. D. (1990): Human Memory. Theory and Practice, Hove / London, Lawrence Erlbaum Ass.

BADDELEY, A. D. (1991): "The Development of the Concept of Working Memory: Implications and Contributions of Neuropsychology", G. Vallar and T. Shallice (Eds.), Neuropsychological Impairments of ShortTerm Memory, New York, Cambridge University Press, pp. 54-73.

BADDELEY, A. D. (1994): "Les mémoires humaines", La Recherche, 267 (25), pp. 730-735.

BADDELEY, A. D. and G. HITCH (1974): "Working Memory", G. A. Bower (Ed.), Recent Advances in Learning and Motivation, Vol. 8, New York, Academic Press.

COHEN, N. J. and L. R. SQUIRE (1980): "Preserved Learning and Retention of Pattern Analyzing Skill in Amnesia: Dissociation of Knowing how and Knowing that", Science, 210, pp. 207-210.

CRAIK, F. I. M. and R. S. LOCKHART (1972): "Levels of Processing: A Framework for Memory Research", Journal of Verbal Learning and Verbal Behavior, 11, pp. 671-684.

DAROे, V. (1989): "The Role of Memory and Attention in Simultaneous Interpretation: A Neurolinguistic Approach", The Interpreters' Newsletter, 2, pp. 50-56.

DAROे, V. (1995): "Memory in Conference Interpretation", S. Lambert (Ed.), A Cognitive Approach to Interpreter Training, Amsterdam, Benjamins (in press).

DARÒ, V. and F. FABBRO (1994): "Verbal Memory during Simultaneous Interpretation: Effects of Phonological Interference", Applied Linguistics, 15, pp. 365-381.

FABBRO, F. (1995): Il cervello dei bilingui. Neurolinguistica del bilinguismo, Milano, Mondadori.

GERVER, D. (1974): "Simultaneous Listening and Speaking and Retention of Prose", Quarterly Journal of Experimental Psychology, 26, pp. 337-341.

GRAF, P. and M. E. J. MASSON (Eds.) (1993): Implicit Memory, Hillsdale (N.J.), Lawrence Erlbaum Ass.

HIRST, W., SPELKE, E. S., REAVES, C. C., CAHARACK, G. and U. NEISSER (1980): "Dividing Attention without Alternation or Automaticity", Journal of Experimental Psychology, 109, pp. 98-117.

ISHAM, W. P. (1994): "Memory for Sentence Form after Simultaneous Interpretation: Evidence both for and against Deverbalization", S. Lambert and B. Moser (Eds.), Empirical Research on Interpretation, Amsterdam, Benjamins, pp. 191-211.

JAMES, W. (1890): Principles of Psychology, New York, Holt.

KINSBOURNE, M. (1987): "Brain Mechanisms and Memory", Human Neurobiology, 6, pp. 81-92.

LAMBERT, S. (1989): "Information Processing among Conference Interpreters: A Test of the Depthof-processing Hypothesis", L. Gran and J. Dodds (Eds.), The Theoretical and Practical Aspects of Teaching Conference Interpretation, Udine, Campanotto, pp. 83-91.

MILLER, G. A. (1956): "The Magical Number Seven, plus or minus Two: Some Limits on our Capacity for Processing Information", Psychological Review, 63, pp. 81-97.

PADILLA, P., BAJO, M. T., CAÑAS, J. J. and F. PADILLA (1994): "Cognitive Processes of Memory in Interpretation", Poster presented at the ICl Conference on Conference Interpretation, Turku (Finland), Aug. 25-27, 1994

PARADIS, M. (1995): "Neurolinguistic Aspects of Implicit and Explicit Memory: Implications for Bilingualism", N. Ellis (Ed.), Implicit and Explicit Language Learning, London, Academic Press.

SCHACTER, D. L. (1987): "Implicit Expressions of Memory in Organic Amnesia: Learning New Facts and Associations", Human Neurobiology, 6, pp. 107-118.

SCOVILLE, W. B. and B. MILNER (1957): "Loss of Recent Memory after Bilateral Hippocampal Lesions", Journal of Neurology, Neurosurgery and Psychiatry, 20, pp. 11-21.

SELESKOVITCH, D. and M. LEDERER (1989): "Pédagogie raisonné de l"interprétation", Paris, Didier Érudition.

SHALLICE, T. and E. K. WARRINGTON (1970): "Independent Functioning of Verbal Memory Stores: A Neuropsychological Study", Quarterly Journal of Experimental Psychology, 22, pp. 261-273.

SHERRY, D. F. and D. L. SCHACTER (1987), "The Evolution of Multiple Memory Systems", Psychalogical Review, 94, pp. 439-454.

SPELKE, E., HIRST, W. and U. NEISSER (1976): "Skills of Divided Attention", Cognition, 4, pp. 215-230.

SQUIRE, L. R. and S. ZOLA-MORGAN (1991): "The Medial Temporal Lobe Memory System", Science, 253, pp. 1380-1386.

THOMPSON, R. F. (1986): "The Neurobiology of Learning and Memory", Science, 233, pp. 941-947.

TULVING, E. (Ed.) (1987): "Human Memory", Human Neurobiology, 6, pp. 67-152.

WARRINGTON, E. K. and T. SHALLICE (1969): "The Selective Impairment of Auditory Verbal Short-time Memory", Brain, 92, pp. 885-896.

WEBER, W. K. (1984): Training Translators and Conference Interpeters, Harcourt Brace Jovanovich.

WEISKRANTZ, L. (1987): "Neuroanatomy of Memory and Amnesia: A Case for Multiple Memory Systems", Human Neurobiology, 6, pp. 93-106. 